\title{
SULT1C2 Gene
}

National Cancer Institute

\section{Source}

National Cancer Institute. SULT1C2 Gene. NCI Thesaurus. Code C116940.

This gene plays a role in the metabolism of small molecules and purine ribonucleotides. 